\title{
Climate change denial as far-right politics: how abandonment of scientific method paved the way for Trump
}

\author{
Gavin Byrne \\ Senior Lecturer, Birmingham Law School, University of Birmingham, UK
}

In this article I show that the form of argument put forward by the climate change denial movement in the United States (US) closely resembles that used in Nazi Germany with regard to Nazi racial definitions. Each involves a rejection of scientific method. This rejection inherently lends itself to far-right politics, which is a philosophy of prejudice. The prevalence of such a philosophy in contemporary American political culture, exemplified through climate change denial, has arguably opened the door for a president of Trump's type. Nevertheless, the US Constitution is far more difficult to suspend than that of the Weimar Republic. As a result, US institutional safeguards against a philosophy of prejudice are likely to hold against a short-term assault on environmental justice in a way that the Weimar Republic's constitutional order did not against Nazism's assault on civil rights. The greater threat to environmental protection in the contemporary US situation is the slow erosion of democratic norms by the Trump administration.

Keywords: Nazism, climate change denial, Donald Trump, scientific method

\section{INTRODUCTION}

The election of Donald J Trump as 45th President of the United States (US) was a victory for two political movements. The first is far-right 'populism'. The second is climate change denial. Substantively, these movements are unconnected. There is no reason to assume that a climate change denier is also a white supremacist, or vice versa. But as we will see, both positions demonstrate the same underlying attitude towards empirical evidence. Far-right racial prejudice requires a rejection of scientific method. The same is true of climate change denial. I will argue here that the climate change denial movement has normalized an anti-scientific discourse around law and policy that has paved the way for an 'Alt-Right', 'post-truth' presidency, just as much as the Trump administration has facilitated substantive antienvironmentalist goals. Nevertheless, as I will also argue, US democratic institutions provide a degree of inherent protection against anti-science political movements. The greater threat to the environmental movement that we see in the Trump administration is a reshaping of the culture of the presidency. No US president can ignore the Constitution. But, as will be discussed, a president can ignore longstanding 'norms' that play a vital role in both democracy and environmental justice.

In section 2, I show how the notion of 'race' in Nazi Germany emerged from a specific approach to scientific method, and in section 3, I show how the climate change denial movement has normalized the same attitude towards scientific method in the contemporary context and at a legislative level in the US. My analysis shows 
that it is no coincidence that the most anti-environmentalist administration in recent memory should also be the most popular with far-right groups and the most authoritarian in tone: ${ }^{1}$ the underlying relationship between policy and fact is the same even if the substantive issues are very different. The section also highlights how the election of Trump as president is a culmination, not an aberration. Political culture in the US makes it both possible and likely that another Trump-like candidate will be elected president again in the future.

In sections 4 and 5, I move from points of comparison to some important points of contrast. In section 4, I argue that the US Constitution offers more robust safeguards against a sudden reversion to authoritarian government than the 'Weimar Constitution' did. I argue that once democratic institutions are preserved, an inherent reliance on fact-based reasoning offers strong reasons to believe that anti-scientific political agendas can be resisted. I use environmental issues to illustrate this point. Finally, in section 5, I argue that the greater threat from the Trump administration to the environmental movement is longer term: it lies in disregard for normal practice when it comes to transparency and judicial nominations.

\section{RACE AND THE ABANDONMENT OF SCIENTIFIC METHOD IN NAZISM}

There is much debate as to the precise meaning of the term 'scientific method'. ${ }^{2}$ Space does not permit a full discussion of this complex issue here. For the purposes of the discussion at hand, I will avoid unpacking the concept and adopt, instead, a very basic working definition. I ask readers to accept, arguendo, that 'scientific method' involves at least the following three steps. We start out with a hypothesis (which might have come from any number of sources). We test that hypothesis empirically. We revise our hypothesis in light of this empirical evidence if necessary. ${ }^{3}$ A commitment to scientific method is a commitment to the notion that we learn more about the world when we follow these three steps. This is true both with regard to the 'hard' sciences and to social sciences.

1. On anti-environmentalism, see C Miller, 'For a Lump of Coal and a Drop of Oil: An Environmentalist's Critique of the Trump Administration's First Year of Energy Policies' (2018) 36 Virginia Environmental Law Journal 185; L Friedrickson et al., 'History of US Presidential Assaults on Modern Environmental Health Protection' (2018) 108(2) American Journal of Public Health 95; and J Hejny 'The Trump Administration and Environmental Policy: Reagan Redux?' (2018) 8 Journal of Environmental Studies and Sciences 197. On far-right support, see National Policy Institute: Become Who We Are Conference 2016, text at <https:// radixjournal.com/2016/11/2016-11-21-long-live-the-emperor/> and T Robb 'Make America Great Again!', The Crusader: The Political Voice of White Christian America (Fall, 2016) 1. Trump's candidacy was endorsed in The Daily Stormer 28 June 2015 and The American Nazi Party Report, 20 September 2015.

2. See P Godfrey-Smith, Theory and Reality: An Introduction to the Philosophy of Science (University of Chicago Press 2009) and L Laudan, 'Theories of Scientific Method from Plato to Mach' (1968) 7(1) History of Science 1.

3. This is roughly Karl Popper's account of 'empirical method' see The Logic of Scientific Discovery (2nd English edn, Routledge 2009) 3-26, any disagreement with this definition is not relevant to the discussion at hand. The point is that this method was abandoned in Nazi Germany on the issue of race. 


\subsection{An unsuccessful search for proof}

Nazism was not a coherent, single, ideology. When the party came to power, there were numerous sub-groups among both party members and supporters. ${ }^{4}$ One strand of Nazism saw itself as rationalist and scientific. The influences behind this side of the movement were global; the 'social Darwinist' movement, for example, was far from unique to early twentieth-century Germany. ${ }^{5}$ The fate of this 'rationalist' or 'scientific' side is instructive for the discussion at hand: an anti-rationalist or counterenlightenment form came to dominate the movement. ${ }^{6}$ The latest developments in science were important to Nazism's military goals. But, as I will demonstrate in this section, when it came to the bigoted parts of their agenda, in particular issues around race, the movement needed to reject scientific method.

The rationalist side of the Nazi movement had its roots in the eugenics and 'racial hygiene' movements of the nineteenth century. Nazi racial hygienists hypothesized that 'Aryan' Germans and 'Non-Aryan' Germans (especially Jews) were from distinct racial groups in biological terms. ${ }^{7}$ This notion had an instinctive appeal to the Nazi movement more generally. This is so for two, connected, reasons.

First, it performed a justificatory or propagandizing role when it came to treating the two 'races' differently. Genetics was a relatively new field of study. Proof that 'Aryans' and 'Non-Aryans' were different genetically would thus have helped enormously with Nazi efforts to portray the movement as world-leading and modern. ${ }^{8}$

Second, as a matter of practicality, the movement needed a means of distinguishing 'Aryans' from 'Non-Aryans' in order to implement a series of laws that persecuted the latter group. The earliest example is illustrative. Section 3.1 of the 'Law for the Restoration of the Professional Civil Service' required all 'Non-Aryans' to be 'retired' ${ }^{9}$ The idea that 'Aryans' and 'Non-Aryans' could be distinguished biologically was thus an appealing way to identify who should be retired and who should not. The First Regulation of this Law provided that if "the Aryan descent is doubtful an opinion of the experts in race research ordered from the Reich Ministry of the Interior must be obtained'. ${ }^{10}$ This was the beginning of so-called 'Ancestral Proof' in Nazi Germany. ${ }^{11}$ After the enactment of various other laws, anyone living in Germany was

4. See KD Bracher, The German Dictatorship: The Origins, Structure and Consequences of National Socialism (Jean Steinberg, tr, Praeger 1985) 15-21 and G Mosse, The Crisis of German Ideology: Intellectual Origins of the Third Reich (Weidenfeld and Nicholson 1966) 1-148.

5. See G Mosse, The Culture of Western Europe: The Nineteenth and Twentieth Centuries (3rd edn, Routledge 2018) 85-101.

6. See G Lukács, The Destruction of Reason (P Palmer, tr, Merlin Press 1980) and Mosse (n 4) 33, 304-5, 317.

7. See Mosse (n 4) and HW Koch, In the Name of the Volk: Political Justice in Hitler's Germany (St Martin's Press 1989) 80-85.

8. See J Herf, Reactionary Modernism: Technology, Culture and Politics in Weimar and the Third Reich (Cambridge University Press 1984); D Peukert, Inside Nazi Germany: Conformity, Opposition and Racism in Everyday Life (R Deveson, tr, Yale University Press 1993) 38-42.

9. Gesetz zur Wiederherstellung des Berufsbeamtentums, Reichsgesetzblatt 7 April 1933.

10. Erste Verordnung zur Durchführung des Gesetzes zur Wiederherstellung des Berufsbeamtentums, Reichsgesetzblatt 11 April 1933.

11. See E Ehrenreich, The Nazi Ancestral Proof: Genealogy, Racial Science and the Final Solution (Indiana University Press 2007). 
required to demonstrate their racial 'acceptability' with the appropriate documentation in order to be afforded 'full political rights'. ${ }^{12}$

'Race', however, is a complex notion in scientific terms. Early classifications of different human races were conducted on the basis of physical traits, in much the same way as we classify animal species. ${ }^{13}$ It is possible to conduct such classification in a way that adheres to scientific method. While there may be room for dispute in terms of what is meant by different terms - 'blond hair' or 'blue eyes', for example - one could set objective physiological criteria for these and thereby empirically test whether a subject falls into one or other category. Numerous large-scale studies had been conducted into the physical characteristics of German Jews from $1886^{14}$ up until 1942. ${ }^{15}$ It was observed that physical features thought to be 'German' were frequently found in Jewish subjects and vice versa. Indeed, it has emerged since that many images of 'Aryans' used in Nazi propaganda were photographs of Jews or so-called 'partial Jews' (Mischlinge). A picture of Jewish baby Hetty Taft was the cover of Sonne ins Hause, a Nazi magazine promoting Aryan family values. ${ }^{16}$ Werner Goldberg's image appeared in Berliner Tagesblatt above the caption 'The Ideal German Soldier'. Goldberg's father was Jewish. ${ }^{17}$ On the other hand, many senior Nazis including Adolf Hitler, Heinrich Himmler and Joseph Goebbels - looked nothing like the tall, blond, blue-eyed, 'pure' German stereotype. The only other major effort to distinguish a Jewish race from the rest of the German population on biological lines was in terms of blood type. These studies yielded a similar result: Jewish subjects were often shown to have supposedly 'Aryan' blood types and vice versa. ${ }^{18}$

The Nazi movement continued to use 'biological' vocabulary in its propaganda and in its laws when it came to the idea of race. But biological testing did not tell the Nazi movement what it wanted to hear. As a result, racial scientists of the Nazi era slowly gave up on the idea of race as a biological term and started to think of it in terms of 'mental characteristics'. The hypothesis was that these races could be distinguished on the basis of essential 'character traits'. ${ }^{19}$ Even at the time, such essentialism about race had been largely debunked. Furthermore, it is not difficult to see how the search for such a set of classifications might be rooted in prejudice: the character types that racial scientists associated with 'Jewish races' are clearly bigoted stereotypes. For example, one claim was that creativity and genius are specifically Aryan character traits, which Jews can mimic but never actually demonstrate

12. See Sections 2.1 and 2.3 of the Reichsburgergesetz ('Reich Citizenship Law') Reichsgesetzblatt 15 September 1935.

13. See C Linneas, A General System of Nature Through the Three Grand Kingdoms (W Turton, tr, Lackington, Allen and Co 1802). It should be noted, however, that early, genuinely scientific, efforts included an inherent 'eurocentrism', see A James 'Making Sense of Race and Racial Classification' in T Zuberi and E Bonilla-Silva (eds), White Logic, White Methods (Rowman and Littlefield 2008) 31.

14. A Zimmerman, 'Anti-Semitism as Skill: Rudolf Virchow's Schulstatistik and the Racial Composition of Germany' (2008) 32(4) Central European History 409.

15. E Fliethmann, 'Vorläufiger Bericht über Antropologische Aufnahmen an Judenfamilien in Tarnow' (1942) 2 Deutsche Forschung im Osten 92. For a summary see Ehrenreich (n 11) 2-9.

16. J Hugler, 'The Perfect Aryan Poster Child Was Jewish', The Telegraph, 1 July 2014.

17. See B Rigg, Hitler's Jewish Soldiers: The Untold Story of Nazi Racial Laws and Men of Jewish Descent in the German Military (University Press of Kansas 2002) 141-2.

18. See P Mazumdar, 'Blood and Soil: The Serology of the Aryan Racial State' (1990) 64 Bulletin of the History of Medicine 187.

19. See Ehrenreich (n 11) 2-13 and Mosse (n 4) 88-107. 
for themselves. A moment's reflection would have revealed a multitude of highprofile counter-examples. Albert Einstein, Gustav Mahler and Felix Mendelssohn were household names in Germany precisely because of their 'creativity' and 'genius'. Nevertheless, it might be possible to test such a hypothesis in a way that adheres to scientific method. Elfriede Fliethmann's study of Jews in the Warsaw ghetto also looked at professions. None of the stereotypes was confirmed. Jews were not overrepresented among lawyers, bankers, and other so-called 'parasitic' professions. Many were engaged in precisely the sorts of 'wholesome' traditional crafts that Nazi propaganda considered the preserve of 'Aryan races'. ${ }^{20}$ There was, then, no proof that German Jews constituted a different 'race' in biological or essentialist terms, nor in terms of professional stereotyping. Furthermore, there was no other reliable, empirically testable, means of distinguishing 'German' from 'Jew' in a way that fitted with the bigoted aspects of the Nazi agenda.

The desperation of the rationalist side of the movement can be seen especially clearly in the wartime work of the geneticist Otmar von Verschuer. Verschuer had searched, in vain, for physiological bases upon which to distinguish 'German' from 'Jew'. When no such bases were found, Verschuer began to define 'Jews' on the basis of 'psychic' characteristics. The nearest thing to evidence that Verschuer presented was a higher suicide rate among Jewish populations in Germany at the time. A proper scientific investigation into possible causes of such a phenomenon would have included the oppressive measures of the regime. Verschuer's study did not. Nor did his study include any analysis of suicide rates among Jewish populations in other eras to control for such a possibility. Verschuer even admitted, at the time, that a 'psychic' categorization had 'no predictive validity'. ${ }^{21}$

It is possible, of course, to classify groups of people geographically. Such a definition of 'Aryan', however, was untenable: senior Nazis such as Adolf Hitler and Alfred Rosenberg were born outside Germany. It would also have undermined expansionist ambitions if the definition of 'German' were taken to mean 'anyone living within the boundaries of Germany in 1933'.22 Such a definition would also have included German Jews. Similarly, a definition of 'Jew' based on religious observance was of little political use. Nazis wished to persecute both those who attended synagogues and kept the Sabbath holy and their atheist children. ${ }^{23}$

At this point, let us return to our working definition of 'scientific method'. The Nazi hypothesis was that German Jews formed a distinct racial group. That hypothesis was tested empirically in multiple ways. It was shown to be false. What happens next is instructive. As we will see in the next two sections, Nazism held on to the hypothesis of a racial distinction, and it started to reject the notion of empirical testing and observation. ${ }^{24}$ In short, when it came to race, the Nazis abandoned scientific method.

20. See Fliethmann (n 15).

21. O Verschuer, 'Rassenbioligie der Juden' (1938) (3) Forshungen zur Judenfrage 137-51, discussed in Ehrenreich (n 11) 5-8.

22. See A Kallis, Fascist Ideology: Territory and Expansionism in Italy and Germany, 19221945 (Routledge 2000).

23. See Gesetz zum Schutze des deutschen Blutes und der deutschen Ehre (the 'First Implementing Provision of the "Reich Citizenship Act"' (n 12) above) Reichsgesetzblatt 14 November 1935. 24. For an in-depth account of how political pressures overrode a commitment to scientific method for eugenicists and racial hygienists in Nazi Germany see P Weindling, Health, Race and German Politics Between National Unification and Nazism 1870-1945 (Cambridge University Press 1989) 488-514. 


\subsection{Science as 'conspiracy'}

The anti-rationalist side of the Nazi movement was made up of numerous, at times competing, sub-groups and traditions. A full account is impossible here. ${ }^{25}$ In what follows, I describe some general commonalities. Anti-rationalists were just as antiSemitic and racist as the social Darwinists and racial hygienists, but the background to their anti-Semitism was different. Instead of rooting their cause in a crude understanding of anthropology and evolution, anti-rationalists were more driven by the idea of a 'spiritual quest' for the German people to achieve their 'destiny'. Some sought to introduce a uniquely German form of Christianity. Many believed in mysticism, including the idea that true Germans were 'people of the sun'. ${ }^{26}$ Their nationalism took the form of a sense that only Aryan Germans had a spiritual connection to the landscape ('blood' connected to 'soil'). ${ }^{27}$ Their anti-Semitism was manifested in the idea that Jews were 'soulless'. ${ }^{28}$

For present purposes, the most relevant unifying feature of anti-rationalist Nazism was a distrust of argument based on empirical evidence: many of the counter-enlightenment movements that influenced anti-rationalist forms of Nazism insisted on a 'sharp separation of science from true reality'. ${ }^{29}$ The sorts of functional knowledge associated with empirical testing were seen as a hindrance to accessing this 'higher' spiritual truth. This was originally a theological idea, associated with the 'primeval' Germanic Christianity of Arthur Bonus, which was somewhat nationalist but not overtly anti-Semitic. ${ }^{30}$ By the time this notion had been adopted by anti-Semites, the 'true reality' separated from empirical observation was being rooted in the 'healthy prejudices' or intuitions of the German Völk (best understood as 'folk' here). ${ }^{31}$

This side of the Nazi movement found it easy, therefore, to disregard evidence that contradicted Nazism's core claims about race. 'Rationalism' was derided as a Jewish or 'materialist' conspiracy. ${ }^{32}$ Those that had conducted more recent research were

25. See Lukács (n 6) and Mosse (n 4).

26. See G Mosse, 'The Mystical Origins of National Socialism' (1961) 22(1) Journal of the History of Ideas 81. This particular myth is a feature of contemporary neo-Nazism and other far-right groups, see N Goodrich-Clarke Black Sun: Aryan Cults, Esoteric Nazism, and the Politics of Identity (New York University Press 2002).

27. See Mosse (n 4) 15-17, 64-6, 303-4.

28. See A Rosenberg, 'The Earth Centred Jew Lacks a Soul' in G Mosse (ed), Nazi Culture: Intellectual, Cultural and Social Life in the Third Reich (S Attanasio et al., tr, WH Allen 1966) $75-9$.

29. See Mosse (n 4) 65. Influenced by Friedrich Nietzsche, Bonus sought to replace 'knowledge-based' forms of theology (which he described as Jewish and Greek) with a 'creative' and 'brave' form, see A Bonus, Religion als Wille: Grundlegende zur neuen Frömmigkeit (Eugen Diederichs, Jena 1915). See generally S Aschheim, The Nietzsche Legacy in Germany 1880-1990 (University of California Press 1992) 201-31.

30. Mosse (n 4) 63-6.

31. 'Völk' literally translates as 'People'. In this context the term had other connotations. The 'Völkisch movement' sought to resurrect an outdoors, traditional, lifestyle, see Mosse (n 4) 4-30. 'Healthy prejudices' is Reich Minister for Justice Otto Thierack's term, see I Müller, Hitler's Justice: The Courts of the Third Reich (D Schneider, tr, Harvard University Press 1991) 72-3.

32. See L Preuss, 'Racial Theory and National Socialist Political Thought' (1934) 15(2) The Southwestern Social Science Quarterly 103 and Mosse (n 4) 306. The regime often used vague terminology to blame Jews for social ills in ways that could not be tested. See also T Adorno, The Jargon of Authenticity (K Tarnowski and F Will, tr, Routledge 2003) and V Klemperer, 
said not to be 'spiritual' enough to grasp the higher truth of 'the racial soul'. Hitler repeatedly criticized attempts at 'objectivity' as a sign of weakness - as he put it, 'Nordic Science' was 'bound to be opposed to the Liberal-Jewish Science'. ${ }^{33}$ 'Science' itself was thus mischaracterized as essentially political.

Nazi propaganda proceeded to use various outdated, discredited sources in order to achieve two interrelated ends. Primarily, these sources were cited as evidence to further the regime's anti-Semitic agenda. In addition, however, they also served a narrative of worldwide conspiracy against the Völk. The very fact that the global scientific community no longer took these anti-rationalist theories seriously was portrayed as evidence that true 'Nordic Science' was being suppressed. In fact, these various sources had been long discredited. So-called 'racial science' (the notion of categorizing human beings into discrete species) was kept alive in Nazi Germany, but it had disappeared elsewhere in the developed world during the interwar years precisely because its hypotheses had been tested and falsified. ${ }^{34}$ The same is true of so-called 'racial anthropology', which had abandoned scientific method by the end of the nineteenth century, let alone by $1933 .{ }^{35}$

Terms like 'reason' and 'truth' were still employed, of course. Often this was an empty rhetorical flourish. ${ }^{36}$ Elsewhere such terms referred to a spiritual, 'inner' truth, rather than to anything informed by empirical evidence. ${ }^{37}$ An example was the issue of how 'Jewish' an individual had to be before they were identified as 'non-Aryan'. If the goal was to create a Germany that was 'rid of Jews' (Judenrein) then 'partial Jews' would also need to be identified and killed. This seemed an impossible task. In Germany at the time there were thought to be millions of Mischlinge (a term which literally translates as 'mix-lings', used to describe individuals with part 'Aryan' and part 'Jewish' ancestry). The regime's official report on this issue concluded that Mischlinge would naturally be attracted to each other and marry. It also asserted that such marriages rarely produced offspring. ${ }^{38}$ There were no studies conducted or referenced in order to support either of these claims. Yet they were still

The Language of the Third Reich (M Brady, tr, Athlone Press 2000). Elsewhere, I discuss the Trump administration's use of similar tactics, see G Byrne, 'The Jargon of "Law and Order": From Nazism to the Trump Campaign via Heidegger', forthcoming in Law, Culture, and the Humanities, available via Online First.

33. A Beyerchen, Scientists under Hitler (Yale University Press 1977) 134.

34. A Beyerchen, 'Rational Means and Irrational Ends: Thoughts on the Technology of Racism in the Third Reich' (1997) 30(3) Central European History 386, 398, see also E Barkan, The Retreat of Scientific Racism: Changing Concepts of Race in Britain and the United States Between the World Wars (Cambridge University Press 1992).

35. Mosse (n 4) 88-97.

36. See Lukács (n 6) 738-9; Ehrenreich (n 11) 1-13; and A Beyerchen 'What We Now Know about Nazism and Science' (1992) 59(3) Social Research 615.

37. See N Baynes (ed), The Speeches of Adolf Hitler Volume 1: April 1922-August 1939 (Oxford University Press 1942) 464, 500. This notion is associated with the later philosophy of Martin Heidegger, see 'Letter on Humanism' in Basic Writings: Martin Heidegger (DF Krell, ed, Routledge 1996) 217, 263. On Heidegger and Nazism see E Faye, Heidegger: The Introduction of Nazism into Philosophy (M Smith, tr, Yale University Press 2009), R Wolin, The Politics of Being: The Political Thought of Martin Heidegger (Columbia University Press 1990) and H Sluga, Heidegger's Crisis: Philosophy and Politics in Nazi Germany (Harvard University Press 1993).

38. F Jentzsch, 'Wie erforscht man die Grösse und Art der deutsch-jüdischen Vermischung (Bastardierung) am Besten?' Bundesarchiv Berlin-Lichterfelde West R39/2. 
described as 'scientific' despite the source for each claim being described as 'popular belief' among 'the Völk'. ${ }^{39}$

In Popper's terms, the regime 'evaded falsification' of a hypothesis. It did so by decrying contrary evidence as a conspiracy. This was done in order to 'preserve the life of a discredited system' ${ }^{40}$ Scientific vocabulary in Nazi Germany became a tool for propaganda. Alongside this we see an increasing reliance on 'spirit' or 'faith' as a form of evidence. This replacement of empirical evidence with strength of conviction is the third core element in Nazism's rejection of scientific method. ${ }^{41}$ This is the very essence of 'prejudice'.

\section{3 'Spiritual' belief in place of evidence}

The 'anti-rationalist' side of Nazism had always been more powerful and always fitted better with Nazi ideology. Far more anti-rationalist academics survived the 'bringinginto-line' legislation. Carl Schmitt and Martin Heidegger were the two most prominent of such figures. Each was at their most 'anti-rational' and anti-science during the World War II era. ${ }^{42}$ The anti-rationalist side was also more powerful politically, particularly among those with a role in shaping the broader ideology: Hitler, Joseph Goebbels, Reich Minister for Propaganda, and Alfred Rosenberg, Commissar for the Supervision of Intellectual and Ideological Education of the NSDAP, were all very much anti-rationalist. ${ }^{43}$

As early as 1931 we can see an anti-scientific element corrupt that which Nazism wished still to call science. For example, the National Socialist Physicians League included among its stated goals the desire to 'overcome rationalism' and 'to recognise the German soul' ${ }^{44}$ Once the Nazis gained power, scientists were placed under increasing pressure to adopt 'the spirit of National Socialism' in their research. ${ }^{45}$ In this context, a 'spiritual' notion of 'Völk' largely replaced the scientific notion of 'race'. ${ }^{46}$

The anti-scientific basis to Nazi racial laws is shown in the manner in which they were applied. The 1933 wave of legislation included 'Laws to Maintain the Purity of the Race'; provisions to exclude 'Non-Aryans' from civic life; and a number of laws that specifically governed 'Jews' ${ }^{47}$ It also included laws against miscegenation. Determinations as to race on the basis of these laws were highly unscientific.

39. Ibid, for a summary and translation of the relevant sections into English, see Ehrenreich (n 11) 11-12.

40. See Popper (n 3) 20.

41. For Popper, strength of belief could never count as evidence for a hypothesis, ibid 24.

42. Schmitt wrote of 'spiritual unity' in State, Movement, People (S Draghici, tr, Plutarch Press 2001). Heidegger's later work called for 'thinking' to replace 'technological' academic endeavour, see The Question Concerning Technology and Other Essays (W Lovitt, tr, Harper and Row 1977) 21.

43. See A Rosenberg, The Myth of the Twentieth Century (Vivian Bird, tr, Noontide Press 1982), generally see N Goodrich-Clarke, The Occult Roots of Nazism: Secret Aryan Cults and their Influence on Nazi Ideology (2nd ed, Taurius Press 2004).

44. R Proctor, Racial Hygiene: Medicine under the Nazis (Harvard University Press 1990) 65.

45. Beyerchen (n 33) 51-6.

46. Proctor (n 44) 61.

47. On the theories of race behind this see Preuss (n 32) 112-14. Lack of substantive basis is shown in frequent amendment and supplementation of these laws; see Beyerchen (n 33) 12-14. 
In cases where a decision was necessary, the relevant government official either relied on the sworn declaration of the individual involved, or made a decision based on physical characteristics, a method that they knew to be bogus. For example, Ehrenreich estimates that fewer than 4 per cent of the Genealogical Authority's examinees actually underwent any biological examination. Although such examinations were performed by professional scientists, they were wildly inconsistent from one case to another. ${ }^{48}$ Nevertheless, the power structure used these tests and certificates to add 'a stamp of scientific legitimacy' ${ }^{49}$ For anti-rationalist Nazis, we must look beyond empirical observation to what is intuitively felt in the heart of the Völk. This 'spiritual', inner-truth was seen as more credible than scientific truth. Völkisch spirit said the race was pure and that was all that mattered. So being truly 'German' (a member of the Völk) was increasingly seen as state of mind. The claim by racist anthropologist Eugen Fischer that 'we instinctively feel' the difference between German and Jew was typical. ${ }^{50}$ Geneticists and anthropologists had thus reverted to racial definitions more akin to those of authoritarian anti-Semites with no scientific pretentions whatsoever. ${ }^{51}$

This is far from the only instance in which Nazism disregarded scientific evidence to inform policy and law. Similar, equally discredited pseudo-science was employed to justify claims about 'criminal types' as about racial types. ${ }^{52}$ Such pseudo-science was used to justify the persecution, compulsory sterilization and murder of the disabled, alcoholics, homosexuals and Romany ${ }^{53}$ The same approach was taken towards history in Nazism's various claims about 'German tradition', ${ }^{54}$ and about German common law in Nazism's claims about law reform. ${ }^{55}$ As I have discussed in detail elsewhere, Nazi-era judges were encouraged to disregard fact and evidence. ${ }^{56}$ This anti-rationalist approach was at the very core of Nazism and is at the very core of far-right politics.

We should not be surprised that this narrative suits authoritarianism. A commitment to revise hypotheses in the face of empirical evidence places such scientific evidence above 'the leader'. It holds him or her to some account. We should also not be surprised that the narrative suits a far-right political agenda. If the hypothesis can never be wrong, then all results are pre-judged. The alternative to scientific method is prejudice, in the truest sense of the word. This is the very nature of bigotry: no evidence to the contrary can change the bigot's mind.

48. Ehrenreich (n 11) 121-33.

49. Ibid 122.

50. Ibid 7. Fischer stressed the value of 'interbreeding' for genetic robustness until 1933. This research was buried, see Proctor (n 44) 40.

51. For example Karl Luegner, Mayor of Vienna (1897-1910) claimed 'I decide who is a Jew' when pressed, Mosse (n 4) 304.

52. Beyerchen (n 33) 80-81.

53. In the name of so-called 'racial hygiene', members of these groups were designated 'lives not worth living'. This started as a process of non-voluntary so-called 'mercy death' for the mentally disabled, but later became a process for the killing of each of these targeted groups; see Proctor (n 44) 177-222 and M Bryant, Confronting the 'Good Death': Nazi Euthanasia on Trial, 1945-1953 (University Press of Colorado 2005) 19-62. See generally Weindling (n 24). 54. See Lukács (n 6) 742-4.

55. See K Löwenstein, 'Law in the Third Reich' (1936) 45 Yale Law Journal 779.

56. See G Byrne, 'Spirit without Letter: How Volkish Nazi Law Falls Outside Fuller's and Hart's Concepts of Law' (2018) 6(1) Comparative Legal History 65. 
Similarly, however, we should not expect consistency from prejudice. Nazism's 'sharp separation of science from true reality ${ }^{\prime 57}$ in a racial context was nowhere to be seen when it came to the functionality of weapons and gas chambers, ${ }^{58}$ or to their research into atomic energy. ${ }^{59}$ Some have confused this use of science with a commitment to scientific method, ${ }^{60}$ but Alan Beyerchen explains this phenomenon better with the idea of 'rational means to irrational ends'. As he puts it, Nazism was anti-rational at the top and at the level of implementation, with an instrumentally rational, bureaucratic level in-between. ${ }^{61}$ The fundamental project flew in the face of scientific evidence, but to achieve its end Nazism could not help but rely on scientific principles. This internal contradiction might serve to render a morally bankrupt regime even less defensible: Nazi scientists who conducted human experiments in concentration camps broadly adhered to scientific method when they did it. ${ }^{62}$ They simply cannot have done so and also believed the regime's anti-science rhetoric. They knew that there was no merit to the racial (and other) distinctions that were offered as justification for what they did. ${ }^{63}$ They did it anyway.

\section{DISCOURSE ON CLIMATE CHANGE IN US LAW-MAKING}

There are multiple reasons why climate change denial has become such a powerful force in the US political and legal context. For a start, fossil fuel companies enjoy the support of prominent figures within the media, ${ }^{64}$ and have supported the campaigns of numerous politicians. ${ }^{65}$ There are also well-documented psychological and economic factors at play in climate denial. ${ }^{66}$ However, my interest here is not in the causes behind climate change denial, but in the forms of argument that such denial has normalized. I will argue here that justifications for climate change denial on a legislative level follow a similar pattern to justifications of racial policy in Nazi Germany: both approaches reject scientific method - and the form of climate change denial has followed broadly the same shifts in pattern as did Nazi claims

57. See Bonus (n 29).

58. See E Kogon, H Langbein and A Ruckerl, Nazi Mass Murder: A Documentary History of the Use of Poison Gas (Yale University Press 1993).

59. See Beyerchen (n 33) 188-98.

60. See Beyerchen (n 34) 390, for examples see D Fraser, Law after Auschwitz: Towards a Jurisprudence of the Holocaust (Carolina Academic Press 2005) and Z Bauman, Modernity and the Holocaust (Cornell University Press 1989).

61. See Beyerchen (n 34) 392.

62. See Proctor (n 44) 217-22.

63. Vershuer, for example, used material from concentration camp experiments, see Procter (n 44), 42-4, even though he admitted that there was 'no predictive validity' to racial distinctions, see (n 21) above.

64. See J Hoggan and R Littlemore, Climate Cover-Up: The Crusade to Deny Global Warming (Greystone Books 2009) 98-107.

65. Ibid 108-119.

66. See K Jylhä et al., 'Denial of Anthropogenic Climate Change: Social Dominance Orientation Helps Explain the Conservative Male Effect in Brazil and Sweden' (2016) 98 Personality and Individual Differences 184; R McDonald et al., 'Personal Experience and the "Psychological Distance” of Climate Change: An Integrative Review' (2015) 44 Journal of Environmental Psychology 109. 
about race. In spite of the fact that the issues of climate denial and race are conceptually distinct, each espouses a structurally similar philosophy of prejudice.

What we will see is that climate change deniers initially sought any form of evidence they could find in support of their hypothesis. Then they sought to discredit existing evidence as the product of a conspiracy. Latterly, they have relied on entirely non-scientific, spiritual, forms of argument.

In order to show all of this, we will have to consider the 'hypothesis' of climate change denial. It is more difficult to clearly articulate than Nazi hypotheses about race. Nazism used its pseudo-science to justify legislative change; typically climate change denial has used the same strategies to prevent such change. As such, climate denial has rarely had to make a positive case. Instead, therefore, let us take the hypothesis of anti-environmentalism to be one of 'business as usual': that is, human beings should continue to behave as they do now, both individually and collectively, without any consideration of the long-term impact that this might have on the planet.

\subsection{An unsuccessful search for proof}

Initially, the climate change denial movement invested large sums of money in trying to make the scientific argument that it needed. ${ }^{67}$ Mechanisms for doing so already existed. As others have charted, many of the 'think-tanks' and 'non-profit institutes' that attempted to influence public debate on behalf of the tobacco industry in the past now agitate for climate change denial on behalf of fossil fuel companies. ${ }^{68}$ These influencers have all broadly followed the model constructed by Phillip Morris, the tobacco company, when it established its so-called 'sound science' programme in 1993. The stated 'overriding objective' of this programme was to 'discredit the Environmental Protection Agency [EPA] report' on the effects of second-hand smoke. ${ }^{69}$ Phillip Morris created an organization named The Advancement of Sound Science Coalition (now The Advancement of Sound Science Center or TASSC) in furtherance of this objective. ${ }^{70}$ TASSC initially focused on trying to recruit credible, academic scientists to its cause in order to challenge any conceivable aspect of EPA reports on this issue. TASSC and groups like them now perform a similar role for the fossil fuel industry in relation to various EPA measures and legislative debates on environmental issues. ${ }^{71}$

As consensus has grown around the fact of global warming, however, it has become increasingly difficult for TASSC and similar groups to find legitimate

67. See R Brulle, 'Institutionalizing Delay: Foundation Funding and the Creation of U.S. Climate Change Counter-Movement Organizations' (2014) 122 Climatic Change 681, 694.

68. C Hamilton, Requiem for a Species: Why We Resist the Truth about Climate Change (Routledge 2011) 104-6.

69. See Ellen Merlo Memo to William Campbell (then CEO of Phillip Morris International), February 17, 1993. Document no. 2021183916/3930. Available at: <http://www.pmdocs.com> accessed 18 July 2019.

70. E Ong and S Glantz, "Constructing "Sound Science" and "Good Epidemiology": Tobacco, Lawyers, and Public Relations Firms' (2001) 91(11) American Journal of Public Health 1749.

71. See S Benegal, 'The Spillover of Race and Racial Attitudes into Public Opinion about Climate Change' (2018) 27(4) Environmental Politics 733, 735-6; and George Monbiot, Heat: How We Can Stop the Planet Burning (Penguin 2006) 20-42. 
scientists willing to debate the core issue. ${ }^{72}$ The evidence is overwhelming (and consensus is increasing). ${ }^{73}$ As a result, the argument of climate change deniers has shifted, much as 'racial purity' arguments moved from physical characteristics, to blood type, and then to mental characteristics. Instead of denying climate change, they began to dispute that such change was caused by humans. ${ }^{74}$ The scientific community has repeatedly and publically countered such scepticism (one example of which is considered below). Latterly, the climate change denial movement has shifted once more. One of its latest twists is to argue that anthropogenic global warming may exist, but that this is good for humanity. This is the current position of The Competitive Enterprise Institute, another 'non-profit' largely funded by fossil fuel and tobacco companies. ${ }^{75}$

None of these 'think-tanks' has provided a credible rebuttal to the scientific consensus around a human cause behind climate change. Instead, they have shifted position multiple times. Nevertheless, their influence has become even more pervasive as a result. As we will see in the next section, these sorts of organizations play a pivotal role in attempts to undermine scientific consensus on the issue of climate change: any narrative that claims a conspiracy requires an alternative narrative that has been 'suppressed' by the conspirators - these groups perform that role in relation to climate change. In doing so, they create public doubt even around an issue where hard evidence is overwhelming and expert opinion is close to unanimous.

\subsection{Science as 'conspiracy'}

As the climate denial argument has metamorphosed, it has retained scientific vocabulary but become increasingly unscientific, just as we saw with Nazism's claims about racial purity. For illustrative purposes, let us consider one striking example, which occurred nine months before Trump even announced his candidacy. The context was a hearing on the 'Clean Power Plan' in September 2014, and it is particularly noteworthy as it was conducted by the House of Representatives Committee on Science, Space, and Technology. If any congressional committee were to defend scientific method, one would expect it to be this one. Astonishingly, however, several members implied that climate science was a global conspiracy, echoing Nazism's claims about 'Western, liberal, science'. This sort of argument was thus at the very core of law-making discourse on climate change issues in the United States well before Trump came to power.

For example, consider the following exchange between Representative Larry Bucshon, of Indiana, Dr John Holdren (then Director of the White House Office of Science and Technology Policy), and Ms Janet McCabe, Acting Assistant Administrator, Office of Air and Radiation, US Environmental Protection Agency, which took place on the 17th of September 2014:

Mr. BUCSHON.... Is it true that this rule [a requirement to reduce carbon emissions] has no effect on the global temperature change?

72. See J Cook et al., 'Consensus on Consensus: A Synthesis of Consensus Estimates on Human-Caused Global Warming' (2016) 11 Environmental Research Letters 1.

73. Ibid, 4-5, see also Miller (n 1) 189-94.

74. See M Milburn and S Conrad, The Politics of Denial (MIT Press 1996) 201-22.

75. See M Ebell, 'Love Global Warming: What's Wrong with Mild Winters Anyway?', Forbes, December 2016. 
Ms. MCCABE. This rule is about cutting carbon pollution, and cutting carbon pollution will help address the contributions to the effects that we are seeing-

Mr. BUCSHON. Because we have heard previous Administrators from the EPA say that it won't. It is not about affecting the global temperature and climate change. ...

Dr. HOLDREN. Yeah, I would like to respond to that if I may.

Mr. BUCSHON. Yeah. I mean, there are public comments out there that that question has been asked and answered saying 'no'.

Dr. HOLDREN. You should look at the scientific literature rather than the public comments. The fact is

Mr. BUCSHON. Of all the climatologists whose career depends on the climate changing to keep themselves publishing articles, yes, I could read that but I don't believe it. ${ }^{76}$

Here, Bucshon cites 'public comments' rather than 'scientific literature'. He even admits that he has not engaged with the relevant research. The reason that he gives for not doing so is that evidence of climate change is part of a conspiracy by 'climatologists'. This is similar to the approach adopted by the Nazi regime on the issue of race: 'public sentiment' is more valid than expert evidence; any study that contradicts such sentiment is ignored as an alleged product of bias. The degree to which the climate change deniers within that committee were uninterested in empirical evidence can also be seen in the manner in which Bucshon interrupted Dr Holdren and prevented him from answering the relevant question. Consider Bucshon's approach below (while implying another conspiracy theory).

Mr. BUCSHON. And is it true that the model that was created to do [a study on the effects of climate change on asthma and heart disease], the EPA paid tens of thousands of dollars to the person to create the model to, in my view, after I have looked at all the science including people who funded the research - the funders of this research that was done are all pretty far left global warming foundations and others that want this data to come out? I mean, I am just saying, it all depends. If you are a medical person and you look at who funds a study and the result of the study, I mean, I look at the first, who funded it, and if people that believe the result funded it, do you see where I am getting at?

Ms. MCCABE. Yes, Congressman-

Mr. BUCSHON. And it is all based on modelling, not on factual information, so I would-I just

Dr. HOLDREN. Can I take a piece of this as well?

Mr. BUCSHON. No, I am over my time so I will just say this and I yield back to the chairman, that scare tactics like that is really appalling to me to use medical information to scare parents that their children about asthma attacks and scare people saying they are going to have heart attacks and you are going to prevent that with this rule in the first year. That is just not factual. And I would argue that we should all on both sides of this discussion avoid scare tactics. ${ }^{77}$

It is difficult to take Rep. Bucshon's claim that he is concerned about time constraints seriously. Time that might have been spent listening to a climate expert address a genuine issue using data was used instead to promote the idea that the relevant data was part of a conspiracy. In spite of this committee's name, Bucshon shows little interest

76. 'The Administration's Climate Plan: Failure by Design', Hearing Before the Committee on Science, Space, and Technology, House of Representatives, One Hundred Thirteenth Congress, 2nd Session, 17 September 2014, 113-94 (US Government Publishing Office, 2015) 52. 77. Ibid 52-3. 
in scientific evidence - if anything, he treats it with disdain. A similar approach was taken by several other members. One of those was Representative Dana Rohrabacher, who seemed uninterested in the actual answers to the questions that he posed. In one exchange, Rohrabacher made a series of erroneous statements about the rates at which Arctic ice is melting and the so-called 'hiatus' in global warming. ${ }^{78}$ Each of these statements contradicted Dr Holdren's actual report. Dr Holdren then explained, again, why Rohrabacher's claims were incorrect or misleading. Rather than address these issues head on, Rohrabacher used the rest of his time to make general claims about how 'there are legitimate scientists on both sides of the various issues' ${ }^{79}$ In spite of several such claims throughout the hearing, none of the climate change deniers actually produced supportive evidence in the "Additional Material for the Record'. By contrast, representatives that supported the plan submitted several such reports. ${ }^{80}$ So while the climate change deniers on this committee mentioned terms like 'science', 'evidence' and 'fact', they had little interest in the relevant studies.

As others have charted, almost every debate among US lawmakers on climate change since the mid-nineties provides further instances of anti-scientific argument by climate change deniers that nonetheless employs scientific vocabulary. ${ }^{81}$ Some of the more glaring examples within that period include a series of hearings arranged to pre-empt the findings of the IPCC Second Assessment on Climate Change 1995 in relation to proof of a human cause to climate change, ${ }^{82}$ the 'Sound Science' Hearings of 2000, ${ }^{83}$ and the House Subcommittee on Energy and Power's hearings on the Energy Tax Prevention Act Bill of 2011. ${ }^{84}$

As with Nazism's claims about race, the move away from genuine scientific method is accompanied by 'cherry picking' data ${ }^{85}$ and by the use of discredited

78. It is now generally accepted that data suggesting a so-called 'slow-down period' is actually consistent with a steady warming trend when allowances are made for short-term variability, see S Rahmstorf et al., 'Global Temperature Evolution: Recent Trends and Some Pitfalls' (2017) Environmental Research Letters 12. The so-called hiatus was based on an incomplete dataset; studies have shown that there was no actual 'slow-down' once missing data from the Arctic region are included; see Huang et al., 'Recently Amplified Arctic Warming has Contributed to a Continual Global Warming Trend' (2017) Nature Climate Change 875.

79. See (n 76), above, 55-7.

80. Ibid Appendix II, 106-21.

81. See C Mooney, The Republican War on Science (Basic Books 2005) 65-102; N Oreskes, Merchants of Doubt: How a Handful of Scientists Obscured the Truth on Issues from Tobacco Smoke to Global Warming (Bloomsbury 2011) 158-71; and Wendy Wagner, 'The "Bad Science" Fiction: Reclaiming the Debate Over the Role of Science in Public Health and Environmental Regulation' (2003) 66(4) Law and Contemporary Problems 63.

82. United States Congress House Committee on Science, Scientific Integrity and Public Trust: The Science Behind Federal Policy Mandates: Case Study 2 - Climate Models and Projections of Potential Climate Impacts of Global Climate Change, Hearing Before the Subcommittee on Energy and the Environment, 104th Congress, 1st Session, November 16th, 1995 (US Government Printing Office, 1996).

83. United States Congress House Subcommittee on Energy and Environment, Strengthening Science at the U.S. Environmental Protection Agency - National Research Council (NRC) Findings, 106th Congress, 2nd Session, 106-97 (US Government Printing Office, 2000).

84. United States Congress House Committee on Energy and Commerce: Subcommittee on Energy and Power, H.R., the Energy Tax Prevention Act of 2011: 112th Congress, 1st Session, February 9, 2011 (US Government Printing Office, 2011).

85. For one, notorious, example see Floor Statement on the Science of Climate Change, Senator James M. Inhofe, Chairman, Committee on Environment and Public Works, Congressional 
sources $^{86}$ to suggest a commitment to science where none exists. As alluded to earlier, the use of scientific vocabulary to support conspiracy theories around the reality of climate change is most pervasive in the continued use of work by various nonprofit 'think-tanks', as discussed in section 3.1. These 'institutes' are funded by fossil fuel companies and by other interest groups. But they are given names that sound entirely neutral - 'The Cato Institute', 'Americans for Prosperity', 'The George C Marshall Institute' - or that suggest dispassionate, scientific, engagement - 'The Advancement of Sound Science Center', 'The Global Climate Coalition'. ${ }^{87}$ The process of using a neutral or academic sounding 'institute' in order to lobby for a political interest is known as 'astroturfing'. The process is so-called because the names chosen for these institutes make them sound like they represent the interests of a 'grass-roots' movement around specific issues like 'Science' and 'Climate'; but they are 'artificial'. 88 'Astroturfing' is thus an advertising technique disguised as committed research. Various institutes are set up to deliver a message indirectly on behalf of a client. They deliver that message to both the general public and to legislators. But they are branded so as to sound objective. Unsurprisingly, this practice is considered ethically dubious: public relations ethics groups and watchdogs actively discourage the practice on the basis that it is highly deceptive. ${ }^{89}$ Nevertheless, it remains common practice in the fossil fuel industry, specifically in its relationship with legislators. ${ }^{90}$

As noted in section 3.1, climate denialism has never managed to settle on a single, unproblematic, alternative explanation for climate change - any more than Nazism could settle on robust racial definitions. Nevertheless, astroturfing in relation to climate change has been extremely effective in its ability to create doubt in the minds of citizens on this issue. Instead of trying to find an alternative explanation for climate change, 'astroturf' organizations have embraced a strategy of trying to 'convince the public, through the media, that climate science is in deep uncertainty'. ${ }^{91}$ Studies have

Record (Senate) Volume 149, Number 113 (Monday, July 28, 2003) S10012-S10023. As a result of the academic papers cited in this address, two scientists issued statements to the effect that their work had been misrepresented. The papers in question were T Wigley, 'The Kyoto Protocol: C02, CH4 and Climate Implications' (1998) 25(13) Geophysical Research Letters 2285 and Stephen Schneider, 'What is "Dangerous" Climate Change?' (2001) 441 Nature 17. The objections of both scientists to how their work had been represented were noted by Senator John McCain, Congressional Record (Senate) Volume 149, Number 154 (Wednesday, October 29, 2003) S13507-S13508.

86. Inhofe (and others) also relied on W Soon and S Balnius, 'Proxy Climatic and Environmental Changes of the Past 1000 Years' (2003) 23 Climate Research 89. This paper was found to have such serious methodological flaws that its publication led to the resignation of half of the editorial board at Climate Research. In the very next volume, the editor-inchief admitted to errors in the review process; see O Kinne, 'Climate Research: An Article Unleashed Worldwide Storms' (2003) 24 Climate Research 197, on this point more generally see Oreskes (n 81) 158-71.

87. See Hoggan and Littlemore (n 64) 31-40, 54-61 and Mooney (n 81) 49-76.

88. See C Cho, M Martens, H Kim and M Rodrigue, 'Astoturfing Global Warming: It Isn't Always Greener on the Other Side of the Fence' (2011) 104 Journal of Business Ethics 571. 89. See K Fitzpatrick and M Palenchar, 'Disclosing Special Interests: Constitutional Restrictions on Front Groups (2006) 18(2) Journal of Public Relations Research 203.

90. See A Hoffman, 'The Culture and Discourse of Climate Skepticism' (2011) 9(1) Strategic Organization 1.

91. This is the stated goal of the American Petroleum Institute's 'Global Science Communication Action Plan', Cho et al. (n 88) 574. 
shown that participants exposed to information from astroturf websites tend to become less certain about the reality of climate change, less convinced of the magnitude of crisis, and less convinced of human responsibility to address the issue. ${ }^{92}$ This focus on the lack of certainty persists, even among participants who are informed about the funding sources of such research, ${ }^{93}$ and even though participants have identified astroturf websites as being 'less credible' ${ }^{94}$

Although none of this deceptive practice has been conducted in order to support a racist agenda, 'astroturf' organizations perform a similar function to so-called 'Nordic Science', as highlighted in section 2.2 above. The vocabulary deployed by such organizations provides a 'stamp of scientific legitimacy' to climate change denial, or at least to the myth that there are 'legitimate scientists on both sides of the argument' as Rohrabacher put it. On the face of it, the idea of 'sound science' seems a lot better than 'unsound science'. But as with the very idea of 'Nordic science', the actual purpose is to subvert or undermine findings produced by a legitimate commitment to scientific method. This deliberate attempt to manufacture confusion about the realities of climate change is so pervasive among anti-environmentalist lawmakers that academics have characterized it as a 'war' or 'assault' on science itself. ${ }^{95}$

\section{3 'Spiritual' belief in place of evidence}

As we will see, climate change deniers have increasingly emphasized the ideological and the 'spiritual', in a manner similar to Nazism's movement towards 'psychic' and 'Volkish' explanations for racial distinctions, as discussed in section 2.3. These 'spiritual' appeals find a receptive audience in the powerful 'religious right' movement in the US. On a range of other issues - from evolution to stem cell research - the religious right movement has been consistently anti-science. ${ }^{96}$ This overtly religious vein in US society has enabled climate change deniers to create uncertainty by harnessing existing, deeply embedded, 'spiritual' modes of political discourse in much the same way that Nazism was able to harness Volkish discourse. It is quite normal for politicians in the US to invoke Christian religious beliefs as a justification for law and policy. ${ }^{97}$ Climate change deniers have been able to use this norm as a means of introducing

92. Cho et al. (n 88) 579 .

93. Ibid 581.

94. Ibid 579.

95. See generally Hoffman ( $\mathrm{n}$ 90) for an overview of this trend in multiple contexts see Mooney (n 81). The Union of Concerned Scientists' Center for Science and Democracy has charted and analysed these sorts of attacks on science by the United States Government since 2001, see <https://www.ucsusa.org/center-science-and-democracy/attacks-on-science> accessed 18 July 2019.

96. See Mooney (n 81) 164-23. The 'intelligent design' movement has operated in a very similar manner, often with the same political figures involved, see B Forrest and P Gross, Creationism's Trojan Horse: The Wedge of Intelligent Design (Oxford University Press 2004). It should be noted that there are many faith-based arguments in favour of environmental protection too, see J Wardekkerab, A Petersen and J van der Sluijsb, 'Ethics and Public Perception of Climate Change: Exploring the Christian Voices in the US Public Debate' (2009) 19(4) Global Environmental Change 512.

97. Ibid; more generally see D Lindsay Faith in the Halls of Power: How Evangelicals Joined the American Elite (Oxford University Press 2007). 
an 'alternative' source to scientific evidence and thereby manufacturing public uncertainty around climate science.

In 2012, for example, Representative Paul Broun Jr described 'all that stuff [he] was taught about evolution and embryology and big bang theory' as 'lies straight from the pit of hell'. The purpose behind such lies, he claimed, was 'to keep me and all the folks who were taught that from understanding that they need a saviour'. ${ }^{98}$ Broun served as a Congressman from 2007 to 2015. He was also a member of the Committee on Space, Science, and Technology throughout that time. More explicitly, Representative John Shimkus quoted biblical passages from both Genesis and the Gospel of St Matthew in support of his belief that 'man will not destroy this earth', but that God will do so at the time of His choosing. ${ }^{99}$ Therefore, Shimkus argued, we have nothing to fear from climate change. He delivered these remarks in his capacity as a member of the United States House Energy Subcommittee on Energy and Environment, during a hearing titled 'Preparing for Climate Change: Adaption Policies and Programs'. ${ }^{100}$ Representative Joe Barton (a member of the Subcommittee on Environment and Economy) referred to the biblical great flood during a 2013 hearing on the Keystone XL pipeline as evidence that climate change is not caused by overdevelopment. ${ }^{101}$ Perhaps the most notorious remarks are those of Senator Inhofe, a member of the United States Senate Committee on Environment and Public Works (a body then chaired by Senator John Barrasso, who also does not believe that climate change is caused by humans and votes accordingly). ${ }^{102}$ According to Senator Inhofe, who has held office for 22 years:

$\ldots$ the Genesis 8:22 that I use in there is that 'as long as the earth remains there will be seed time and harvest, cold and heat, winter and summer, day and night,' my point is, God's still up there. The arrogance of people to think that we, human beings, would be able to change what $\mathrm{He}$ is doing in the climate is to me outrageous. ${ }^{103}$

These are not fringe positions. These claims are made by longstanding Republican Congressmen and Senators, members of what is termed the 'Grand Old Party'. At the time of writing, Republicans also enjoy a majority in the US Senate. Most of these remarks have been made during Congressional and Senate hearings on the passage of legislation.

Substantively, these issues of climate denial have nothing to do with race or with anti-Semitism. However, the justificatory methodology and approach to empirical evidence is broadly the same as that employed by the Nazi movement in relation to race: there is a hypothesis; scientific evidence is overwhelmingly against that hypothesis; the hypothesis is retained, and different forms of scientific evidence are frantically

98. Speech delivered at 'The Liberty Baptist Church Sportsman's Banquet', Hartwell, Georgia, September 27th 2012.

99. The relevant passages are Genesis 8:21 and 8:22, and Matthew 24:31. Government Publishing Office, 2012) 9.

101. 'HR3, The Northern Route Approval Act', Hearing Before the Subcommittee on Energy and Power, of the Committee on Energy and Commerce, House of Representatives, One Hundred Thirteenth Congress, 1st Session, 10 April 2013, 113-26 (US Government Publishing Office, 2013) 67.

102. Barrasso does not dispute that climate is changing, see his interview on C-SPAN, Newsmakers with John Barrasso June 5, 2014 available at <https://www.c-span.org/video/?3197851/newsmakers-sen-john-barrasso-r-wy>.

103. 'Crosstalk with Vic Eliason', Voice of Christian Youth America Radio, 7 March, 2012. 
sought (thus 'evading falsification'). None of these alternative forms of evidence support the original hypothesis. The hypothesis is nonetheless retained, and evidence to the contrary is denigrated as a 'conspiracy'. The justification for this dynamic becomes increasingly non-scientific, in spite of some use of scientific vocabulary and of cherry-picked sources. Ultimately, the argument becomes a 'spiritual' appeal. The one constant in the process is that the original hypothesis can never be revised.

There is another clear parallelism to the Nazi abandonment of scientific method in defence of its ideologically driven racial policy: the simultaneous abandonment and invocation of science. The climate change denial movement ignores, downplays or contradicts science. Yet even as it does so, the fossil fuel industry that it protects, promotes and relies on science. ${ }^{104}$ The forces behind the climate denial movement are willing to jettison the method that founded the fossil fuel industry they defend (scientific method led to the discovery of coal and oil as fuel sources and the industry remains reliant on innovations that use scientific method to improve extraction techniques and identify viable mines and wells), while specifically abandoning scientific method when it comes to climate change. Once again, as in the case of the Nazis, this inconsistency is all the more damning because scientists involved in the fossil fuel industry and elsewhere are fully aware of the reality of climate change. The major executives at each one of these multinationals are fully aware of the realities too. ${ }^{105}$ These actors have no firm commitment to an anti-rationalist (or counterenlightenment) philosophical agenda. They are just willing to embrace it in order to pursue another goal.

\section{4 'AUTHORITARIAN REVERSION' AND ENVIRONMENTAL PROTECTION}

Donald Trump's candidacy and presidency have consistently displayed the same philosophy of prejudice that we have identified in the Nazi movement and in the operation of climate change denial in the US. The hypothesis - what Trump feels in his heart - is sacred. It is never to be revised. What is required to verify the hypothesis is utterly malleable. According to the Trump administration, empirical evidence to the contrary must be the product of a conspiracy; 'you shouldn't trust what you see and hear'; ${ }^{106}$ 'truth isn't truth'; ${ }^{107}$ 'the president has alternative facts' ${ }^{108}$ This dynamic is clear in Trump's positions on a series of race-related legal issues, from his central

104. See V Smil, Energy and Civilization: A History (The MIT Press 2017) 225-384.

105. The clearest example is that of ExxonMobil, see N Banerjee, J Cushman Jr, D Hasemyer and L Song, Exxon: The Road Not Taken (CreateSpace Independent Publishing Platform 2015); and see generally $\mathrm{M}$ Boon, 'A Climate of Change? The Oil Industry and Decarbonization in Historical Perspective’ (2019) 93 Business History Review 101.

106. See Remarks by President Trump at the Veterans of Foreign Wars of the United States National Convention, Kansas City, MO, July 24, (2018), available at <https://www.whitehouse. gov/briefings-statements/remarks-president-trump-veterans-foreign-wars-united-states-nationalconvention-kansas-city-mo/>.

107. The quotation is from Rudy Giuliani, Personal Attorney to United States President Donald Trump, on NBC's Meet the Press With Chuck Todd (2018) available at <https://www.nbcnews. com/meet-the-press/meet-press-august-19-2018-n901986>.

108. Kellyanne Conway, Counsellor to United States President Donald Trump, on NBC's Meet the Press With Chuck Todd (2017) available at <https://www.nbcnews.com/meet-the-press/ meet-press-01-22-17-n710491>. Vice-President Mike Pence is a longstanding political member 
involvement in the 'birther movement' 109 to his position on the 'Central Park Five'. ${ }^{110}$ It is also clearly illustrated in Trump's position on climate change. Confronted with a detailed Climate Change Assessment from the United States Government's own Global Change Research Programme, ${ }^{111}$ Trump dismissed the findings, saying simply 'I don't believe it'. ${ }^{112}$ No amount of evidence was going to change his position, not even in a report from the heads of 13 different agencies within his own government.

Trump's positions on race and the environment appear to have little in common substantively. But what I have termed the 'philosophy of prejudice' lies behind both. As we have seen, an unwillingness to adjust prejudices around climate change, even in light of overwhelming evidence to the contrary, has long been normalized in American politics. In this respect, therefore, the rise of Trumpism (and of 'post-truth politics' generally), has been facilitated by the climate change denial movement. Given these background conditions, it should not come as a great surprise that a 'post-truth' president has been elected. We should take it as likely, moreover, that another such figure will be elected in the future. This likelihood raises the obvious question as to how easily such an administration can achieve its anti-scientific agenda as a practical matter. An anti-scientific attitude alone will not achieve 'prejudiced' ends (be they racial or anti-environmental). In this section I show that the Constitution of the United States is more resistant to the sort of overnight destruction of democratic institutions than was the Weimar Republic at the time of the rise of Nazism. As such, the Trump administration, and future, similar, administrations, will continue to face resistance to the anti-science, anti-environmental agenda in a way that Nazism did not in relation to its anti-science, anti-Semitic agenda.

\subsection{Constitutional resistance}

The Trump administration has already done serious damage to the planet. To name but a few examples, it has relaxed safety rules around off-shore drilling, ${ }^{113}$ increased

of the 'anti-science' movement, especially with regard to the dangers of cigarette smoke, see M D'Antonio and P Eisner, Shadow President: The Truth about Mike Pence (St Martin's Press 2018) 82-101.

109. Trump was part of a movement that hypothesized that 44th President Barack Obama was born in Kenya. The hypothesis was disproven by the production of Obama's birth certificate; Trump and other 'birthers' then claimed that the certificate was a forgery instead of accepting that the hypothesis was wrong. See E Hehman et al., 'Evaluations of Presidential Performance: Race, Prejudice, and Perceptions of Americanism' (2011) 47(2) Journal of Experimental Psychology 430.

110. In spite of weighty physical evidence, corroborated by a confession, and a full exoneration, Trump maintains that the 'Central Park Five' are guilty to this day. See J Ransom, 'Trump Will Not Apologize for Calling for Death Penalty Over Central Park Five', New York Times, 18 June 2019. See generally, HA Giroux 'White Nationalism, Armed Culture and State Violence in the Age of Donald Trump' (2017) 43(9) Philosophy and Social Criticism 887.

111. See DJ Wuebbles et al. (eds), Climate Science Special Report: Fourth National Climate Assessment, Volume II (U.S. Global Change Research Program, Washington, DC, 2018) available at $<$ https://nca2018.globalchange.gov/>.

112. 'Trump on Own Administration's Climate Report: "I Don't Believe It", The Guardian, 26 November 2018.

113. Department of the Interior Bureau of Safety and Environmental Enforcement 30 CFR Part 250 [Docket ID: BSEE-2018-0002; 190E1700D2 ET1SF0000.EAQ000 EEEE500000] RIN 
logging on federal lands, ${ }^{114}$ drastically reduced criminal prosecutions for environmental offences, ${ }^{115}$ started to remove restrictions on greenhouse gas emissions from coalbased power plants, ${ }^{116}$ and cut NASA's Carbon Monitoring System. ${ }^{117}$ Such damage will continue. Much of it is lasting. ${ }^{118}$ All of this damage serves to place the constitutional limits on the presidency in sharp focus for environmentalists. In this respect, Trump's authoritarian language is worrying. He has openly spoken about the merits of extending presidential terms. ${ }^{119}$ He has shown disdain for the notion of due process, in particular for judicial oversight of executive functions. ${ }^{120}$ His campaign policies included limitations to press freedom, and throughout his presidency he has denigrated the press as 'enemies of the people'. ${ }^{121}$ There are, however, at least three strong reasons to believe that Trump's capacity to harm the environment if he secures a second term will remain within constitutional limits, in contrast to Nazism's capacity to perpetrate genocide. The same reasons apply to a future Trump-like presidency - at least for the time being.

First, Trump's motivations are nothing like as clear as those of the Nazi movement. He has not indicated any desire to usurp territories or to build an empire. Furthermore, Trump may care little for the environment, but he does not appear to have a fanatical desire to harm the planet in the same way that an all-consuming, virulent, anti-Semitism drove Nazism. Trump has authoritarian instincts, but he does not have the same pressing need to expand executive powers. Both his need and his desire to overcome existing constitutional limits seem slight by comparison to Nazism.

Second, the contemporary US may be polarized politically, but it does not fit the broader social model for countries that tend to become undemocratic overnight. The recent work of Aziz Huq and Tom Ginsburg is informative in this respect. ${ }^{122}$

1014-AA39 Oil and Gas and Sulfur Operations in the Outer Continental Shelf-Blowout Preventer Systems and Well Control Revisions Federal Register 31343 Vol. 83, No. 129, Thursday, 5th July, 2018.

114. United States Executive Order of President Donald Trump 3372: Promoting Active Management of America's Forests, Rangelands, and other Federal Lands to Improve Conditions and Reduce Wildfire Risk, 21st December 2018.

115. Public Employees for Environmental Responsibility, 'Criminal Enforcement Collapse at EPA: Lowest Number of New Anti-Pollution Cases in 30 Years', 15 July 2019, available at $<$ https://www.peer.org/news/press-releases/criminal-enforcement-collapse-at-epa.html> accessed 21 October 2019.

116. Environmental Protection Agency 40 CFR Part 60 [EPA-HQ-OAR-2013-0495; FRL9987-85- OAR] RIN 2060-AT56 Review of Standards of Performance for Greenhouse Gas Emissions from New, Modified, and Reconstructed Stationary Sources: Electric Utility Generating Units Federal Register, Vol. 83, No. 244, Thursday, 20th December 2018.

117. P Voosen, 'NASA Cancels Carbon Monitoring Research Programme' (2018) 360 Science 586.

118. See Miller (n 1) and 'Environmental Law Under Trump: Symposium' 48(2) Environmental Law Journal.

119. 'Trump is Already Campaigning for the End of Presidential Term Limits', Washington Post, 14 May 2018.

120. 'President Trump Calls for Immediate Deportation of Undocumented Immigrants "With No Judges or Court Cases", Time, 24 June 2018.

121. R Andersen Jones and SR West 'The Fragility of the Free American Press' (2018) 112(3) Northwestern Law Review 567, 584-93.

122. A Huq and T Ginsburg, 'How to Lose a Constitutional Democracy' (2018) 65 UCLA Law Review 78. 
They provide a detailed study of how constitutional democracies are lost. They identify two pathways. The first is 'authoritarian reversion', ${ }^{123}$ whereby a country swiftly and suddenly reverts from a constitutional democracy to a form of authoritarian government. Typically this happens as the result of a coup d'état, an invasion, or an emergency declaration. The movement from Weimar Republic to Nazi dictatorship in a matter of months is one of the best-known examples of this. As Huq and Ginsburg explain, the contemporary US is an unlikely candidate for such a sudden change. ${ }^{124}$ It is an 'old' democracy: its constitution was written in 1787 . When authoritarian reversions take place, the constitution in question tends to be a much more recent document. For example, The Constitution of the German Reich (the 'Weimar Constitution') was ratified in 1919 and suspended in 1933. In addition, while wealth is unevenly distributed, the US is not currently experiencing an economic crisis of the sort that tends to precipitate an abrupt switch from democracy to dictatorship. ${ }^{125}$

Third, and perhaps most significantly, it is much more difficult for Trump to legally suspend the United States Constitution in the way that the Nazis succeeded in suspending the Weimar Constitution. Like the United States Constitution, the Weimar Constitution contained numerous checks on executive power. These included guarantees on the separation of powers. It also included term limits for the head of the executive. ${ }^{126}$ Under Article 48, however, the President of the Reich was entitled to 'temporarily' suspend fundamental rights contained elsewhere 'if public security and order are seriously disturbed or endangered within the German Reich'. On the 27th of February 1933, the Reichstag caught fire, and the Nazi Party very publically blamed this on a plot by the Communist Party. Hitler, as Reich Chancellor, convinced Reich President Hindenberg that the Reichstag fire required a suspension of rights under Article 48 . Hindenberg duly signed what has come to be known as the 'Reichstag Fire Decree'. ${ }^{127}$ In theory, these emergency powers were revocable by the Reich President or the Reichstag. But their effect was to chill political discourse and silence any dissent. In particular, the developments all but eliminated the Communist Party from the ensuing elections. A coalition of the Nazi Party and the German National People's Party made up a narrow majority in the Reichstag. The Nazis used Fire Decree powers to prevent many members of the Reichstag from attending. An intimidated, coerced and truncated Reichstag then narrowly passed what has come to be known as 'The Enabling Act'. ${ }^{128}$ This gave the Cabinet authority to issue decrees without the assent of the Reichstag. In effect, these two documents established martial law in Nazi Germany. ${ }^{129}$ Article 48 of the Weimar Constitution was, thus, a key tool for the Nazi movement in their usurpation of power. It is one of the main reasons why Germany could move from democracy to dictatorship so quickly. ${ }^{130}$

123. Ibid 92-4.

124. Ibid 105-17.

125. Ibid 102-5.

126. Section III, Article 43.

127. Verordnung des Reichspräsidenten zum Schutz von Volk und Staat, 28th February 1933.

128. Gesetz zur Behebung der Not von Volk und Reich (Ermächtigungsgesetz) Reichsgesetzblatt, 23rd March 1933.

129. See generally Müller (n 31) 27-35.

130. Ibid 43-49. 
The US Constitution offers no equivalent express emergency powers to the office of President (much less ones that are so sweeping). ${ }^{131}$ Express emergency provisions are granted to Congress instead. ${ }^{132}$ Procedures for almost all emergency provisions have a jurisprudence of their own, together with well-established procedures and limitations. In many cases, these procedures are on a statutory footing and the relevant provisions specify which rights might be suspended and for how long. ${ }^{133}$ Executive powers to respond to an 'act of terror' (like the Reichstag fire) are now prescribed in 'The Patriot Act'. ${ }^{134}$ Many of these provisions have been used to curtail or undermine individual liberties in the interests of national security, which has been a matter of concern for constitutional and human rights scholars for some time. ${ }^{135}$ But this array of provisions and powers means that it is difficult to imagine an emergency situation that would allow the Trump Administration (or any other) to suspend the Constitution itself, indefinitely, in the manner that the Reichstag Fire Decree did for Nazism. Even the most notorious executive incursion into civil liberties in recent memory - the internment of Japanese Americans during World War II - amounted to an assault on the civil liberties of a group within society rather than an outright suspension of the rights themselves. And nor did this incursion abolish a free press or the opportunity to challenge the order constitutionally. ${ }^{136}$

Once the Weimar Constitution was suspended, legislative repeal became a very simple matter for the Nazi regime: Article 1 of The Enabling Act allowed the Cabinet to create law. The Trump Administration, by contrast, has to remain within existing constitutional restraints. This level of restraint impedes its efforts to amend or repeal environmental legislation, because any such attempt requires House and Senate approval under Article 1, Section 1 of the US Constitution. Thus, although there have been several proposals to date that would seriously restrict environmental protection, particularly with regard to the scope of the Endangered Species Act $1973,{ }^{137}$ outright repeal of major environmental legislation seems highly unlikely even if Trump secures a second term of office. Thus far, Trump has struggled to fulfil his existing legislative programme even when it comes to issues that are high on the Republican agenda. ${ }^{138}$

131. Express powers of the president are enumerated under Article II. Emergency powers have been implied in executive powers, see C Edelson and L Fisher, Emergency Presidential Power: From the Drafting of the Constitution to the War on Terror (University of Wisconsin Press 2013) 7-20.

132. Article I, ss $8,9$.

133. See generally Huq and Ginsburg (n 122) 110-11. Congressional constraints on the implied emergency powers of the President are enumerated in The National Emergencies Act, Pub. L. 94-412, 90 Stat. 1255, 50 U.S.C. § 1601-1651 (1976).

134. Uniting and Strengthening America by Providing Appropriate Tools Required to Intercept and Obstruct Terrorism Act, Pub. L. 107-56, 115 Stat. 272 (2001), as amended by the Uniting and Strengthening America by Fulfilling Rights and Ending Eavesdropping, Dragnet-collection and Online Monitoring Act, H.R. 2048, Pub. L. 114-23 (2015).

135. See S Herman, Taking Liberties: The War on Terror and the Erosion of American Democracy (Oxford University Press 2011).

136. See Korematsu v United States (1944) 323 U.S. 214. The Supreme Court recently suggested that even this incursion is unlikely to be upheld now, see Trump v Hawaii, No. 17-965, 585 U.S. _ (2018).

137. 16 U.S.C. $\$ 1531$ et seq. (1973).

138. This is evident in healthcare reform. For almost a decade, Republicans have called for the repeal of The Patient Protection and Affordable Care Act, 201042 U.S.C. $§ 18001$ et seq. (2010). 
Constitutional amendment under Article $\mathrm{V}$ is even less likely, given that it requires a two-thirds majority of both houses. More generally, it is rare to find the political will within Congress to amend the Constitution; the culture is unusually averse to such amendment. ${ }^{139}$ We can thus conclude with some degree of certainty that the Trump administration will have to remain within the broad bounds of existing executive powers in its efforts to reverse environmental protection. The same is true of future administrations. While these institutional protections cannot guarantee against damage to the environment or to the environmental movement, in the short term at least they provide a safeguard against the philosophy of prejudice - particularly when we consider the constitutional protections in place for both state rights and the judiciary.

\subsection{Federalism}

The Executive branch of the Federal Government in the US has considerable power when it comes to environmental issues. The Environmental Protection Agency (EPA) has the primary responsibility for both the creation and enforcement of national standards. Trump appointed Scott Pruitt as its head. ${ }^{140}$ Pruitt is an avowed anti-environmentalist. He spent a disproportionate amount of his career as Attorney General of Oklahoma bringing various legal actions against the EPA. ${ }^{141}$ Pruitt recently resigned. ${ }^{142}$ His replacement as acting head of the EPA is former coal lobbyist, Andrew Wheeler. ${ }^{143}$ A full-time successor has yet to be nominated, but we might reasonably assume that the tenures of Pruitt and Wheeler provide a blueprint for the future. ${ }^{144}$ That blueprint is a combination of deregulation and inaction. ${ }^{145}$ It is one that largely contradicts the essential goal of environmental protection and supports the goals of polluters. In deregulatory terms, Trump's EPA has already loosened the restrictions on toxic air pollution from industrial sources. ${ }^{146}$ Similar plans are underway with regard to greenhouse gas

Even with Republican control of both Houses of Congress, the administration failed to fulfil this pledge. Tellingly, the derailment came after the Congressional Budget Office had an opportunity to 'score' the Senate version of the Bill in terms of its true costs and effects. Congressional Budget Office Cost Estimate, 26 June 2017 H.R. 1628 Better Care Reconciliation Act of 2017: An Amendment in the Nature of a Substitute [LYN17343].

139. R Albert, 'Constitutional Disuse or Desuetude: The Case of Article V' (2014) 94 Boston University Law Review 1029.

140. 17 February 2017

141. See S Sismondo, 'Post-Truth?' (2017) 47(1) Social Studies of Science 3; E Bloomberg, 'Environmental Politics in the Trump Era: An Early Assessment' (2017) 26(5) Environmental Politics 956.

142. 6 July 2018.

143. See A Adams, 'What to Know About Andrew Wheeler, A Former Coal Lobbyist Who Will Temporarily Replace Scott Pruitt as EPA Chief', Time, 6 July 1998, available at $<$ https://time.com/5331352/andrew-wheeler-epa/>.

144. See Miller (n 1) 260-8 and B Sherman, 'The Upside Down: A New Reality for Science at the EPA and Its Impact on Environmental Justice' (2019) 27 New York University Environmental Law Journal 57.

145. Ibid.

146. Memo titled 'Reclassification of Major Sources as Area Sources Under Section 112 of the Clean Air Act' January 25th, 2018, accessed at <https://www.epa.gov/stationary-sources-airpollution/reclassification-major-sources-area-sources-under-section-112-clean>. 
emissions from coal fired plants, ${ }^{147}$ and with regard to vehicle emissions standards. ${ }^{148}$ In terms of inaction, a large proportion of key posts within the EPA have still not been filled. ${ }^{149}$

Nevertheless, there are several reasons why anti-environment goals can be frustrated and resisted legally at state level (even if such state protections are no substitute for the effect of a national commitment to environmental protection). ${ }^{150}$ Under Massachussetts $v E P A$, individual states have standing to sue the EPA into action on various pieces of legislation. ${ }^{151}$ States can also sue emitters directly under the Clean Air Act. ${ }^{152}$ Even if this administration manages to all but destroy the EPA itself, individual states retain a large amount of power when it comes to environmental issues. ${ }^{153}$ This would also be true of any similarly minded future administration. We see this most clearly in the special dispensation that California has to set its own vehicle emissions standards. ${ }^{154}$ Individual states have the option of following either the EPA standard or that of the California Air Resources Board (CARB); 13 states plus the District of Colombia have adopted the latter course. The EPA agreed to adopt the California standard from 2016. The EPA is not bound by this standard. But California is the largest market for vehicle purchase in the United States. ${ }^{155}$ Other CARB states include New York, Pennsylvania and Massachusetts. This means that California in effect sets the standard for all vehicle manufacture. If California wished to make its requirements stricter still, this would require EPA approval, but those requirements cannot be made less strict by executive action. This is to say nothing of the degree to which individual states and cities can still pursue an environmentally responsible agenda in terms of matters like procurement and waste disposal. Within days of Trump's withdrawal from the Paris Agreement, 160 mayors of major cities across the United States pledged to honour the agreement anyway. ${ }^{156}$

147. See the proposed 'Affordable Clean Energy Rule', accessed at <https://www.epa.gov/ stationary-sources-air-pollution/proposal-affordable-clean-energy-ace-rule>.

148. See the proposed 'Safer Affordable Fuel Efficient Vehicles Rule', accessed at <https:// www.epa.gov/regulations-emissions-vehicles-and-engines/safer-affordable-fuel-efficient-safevehicles-proposed>.

149. '85 Percent of the Top Science Jobs in Trump's Government Don't Even Have a Nominee', Washington Post, 6 June 2017.

150. Recent studies have shown that state and local action will not be enough to meet obligations under the Paris Climate Change Agreement, see Global Climate Action from Cities, Regions and Businesses (Data Driven Yale, NewClimate Institute, PBL, 2018). My focus is the specific issue of environmental justice in the immediate to short term; it is not to suggest that the federal system provides a permanent protection against a potential, slower, slide into authoritarianism, for discussion see Huq and Ginsburg (n 122) 160-2.

151. (2007) 549 U.S. 497.

152. Pruitt was of the view that individual states, and not the EPA, should be the primary force for environmental protection in the United States; see Testimony before the Senate Environmental and Public Works Subcommittee on Clean Air and Nuclear Safety, 'Legal Implications of the Clean Power Plan', E Scott Pruitt, Attorney General, State of Oklahoma, 5th May 2015. 153. See generally D Rosner, 'States Protecting the Public Interest in the Era of Trump' (2018) 96(1) The Milibank Quarterly 25.

154. The Clean Air Act, 42 U.S. Code $§ 7401$ et seq., at $§ 7543$.

155. See Highway Statistics 2017 (United States Department of Transportation), s 7.3.1. Available at $<$ https://www.fhwa.dot.gov/policyinformation/statistics/2017/>.

156. See 'Climate Mayors Letter to President Trump on Roll Back of U.S. Climate Actions', 28 March 2017, available at <http://climatemayors.org/actions/letters-and-statements/>. On the general possibility of state resistance to Federal power see K Scott, Federalism: A Normative Theory and its Political Relevance (Bloomsbury 2011). 
Here we can see, then, how the constitutional protections discussed in section 4.1 are likely to protect the environmental movement even against an aspiring authoritarian and anti-environmentalist administration. Under the Tenth Amendment of the United States Constitution, there is nothing that the federal government can do to stop individual states from pursuing the goals outlined in the Paris Agreement: any power not expressly delegated to the federal government is reserved by individual states. While the Weimar Constitution contained a very similar provision under Article 5, that provision was suspended by sections 2 and 3 of the Reichstag Fire Decree, which eliminated the possibility that individual states (or Länder) might hinder Nazi racial goals by setting their own standards and regulatory frameworks or by simply maintaining the norms of state-level policing and adjudication.

In the US, then, individual states retain standing to pursue environmentalist agendas on their own, and standing to sue the federal government for any failures in this regard. The latter, however, is only meaningful if there is a functioning judiciary - an issue to which we will now turn.

\subsection{Independent judiciary}

There are reasons to believe that judicial resistance is not only possible but likely. When we contrast the Trumpist assault on environmental protection with the Nazi assault on civil liberties, there are reasons for cautious optimism, rooted in a combination of constitutional robustness and an inherent, institutional, reliance on empirical evidence in the US.

One month after the passage of the Enabling Act, the Nazi regime passed The Law for the Restoration of the Professional Civil Service. ${ }^{157}$ Under Article 3.1, all 'nonAryan' civil servants were to be retired; under Article 4 the same was true of those 'whose former political activity affords no guarantee that they will act in the interest of the national state at all times and without reservation'. Under Article 7 there was no right to appeal. The Law on Admission to the Legal Profession contained parallel provisions with regard to legal practitioners. ${ }^{158}$ With the passage of these Acts, the regime was able to purge the judiciary of both Jews and political opponents. Some members of the judiciary continued to resist the regime in whatever ways they could,${ }^{159}$ but the broad effect of these laws was to remove existing judicial resistance at both federal and state level. Such legislation was only possible because the Weimar Constitution had been suspended. Multiple provisions would have been transgressed otherwise. For example, Article 104 rendered suspension of judges a judicial matter. Article 130 stated, inter alia, that '[1]iberty of political opinion ... is guaranteed to all public officials'. And Article 136 guaranteed, inter alia, that 'eligibility of public office [is] independent of religious belief'.

Once a largely compliant judiciary had been installed, the Reich Ministry of Justice put forward various 'guidelines' (Richterbriefe) to instruct the judiciary on how they wanted cases to be decided. There is evidence that Nazi judges found it difficult to

157. Gesetz zur Wiederherstellung des Berufsbeamtentums, Reichsgesetzblatt (April 7th, 1933).

158. Gesetz über die Zulassung zur Rechtsanwaltschaft, Reichsgesetzblatt (April 7th, 1933) ss 2 and 3.

159. See H Pauer-Studer, 'Law and Morality under Evil Conditions: The SS Judge Konrad Morgen' (2012) 3(2) Jurisprudence 367. 
adhere to these guidelines while still acting in a way that they considered to be 'adjudication' at all. In part, this was precisely because of the regime's hostility to empirical evidence. ${ }^{160}$ One example that is particularly relevant is the issue of sentencing. Numerous Richterbriefe instructed judges to provide harsher sentences 'even if the offence for which [the accused] is being judged does not appear to justify the most severe sentence'. ${ }^{161}$ In response to this sort of instruction, the President of the Higher State Court in Cologne wrote the following in his report to the Ministry in 1942:

I and the General Prosecutor continue to regard the 'steering of sentencing' ... as a serious burden from the point of view of both the workload involved and our professional consciences. To intervene in the process by which a judge decides on a sentence, at a stage and with methods which do not permit a full assessment of the deed or the accused, strictly speaking represents a sin against what we, more than any other professional body, should regard as sacred, namely the law. ${ }^{162}$

The reason for the tension that we can see here between the senior leadership and the judiciary was the same as for the tension between that leadership and genuine science. The judiciary found it virtually impossible to continue the act of judging without placing some sort of emphasis on empirical evidence. This was true even for Nazi loyalists within the judiciary, let alone for the few that tried to act as something of a buttress against the regime. ${ }^{163}$ Facts and evidence are important in adjudication, just as they are central to the scientific method. The experience in Nazi Germany suggests that if a regime is unwilling to accept the significance of evidence and fact, it will find it very difficult to exist alongside a judicial system (even a 'degenerated' one). ${ }^{164}$ A Nazi judiciary that had been 'brought into line' ideologically and faced dismissal if it defied the executive still found it difficult to ignore facts and continue to act as judges.

It is even less likely that the judiciary of the Trump era (and the immediate future beyond that) will be able simply to ignore facts in pursuit of anti-environmentalist ambitions. The President has no say in judicial appointments at state level. Neither Trump nor any other anti-environmentalist president could use executive power to remove existing federal judges who believe in upholding environmental protections. ${ }^{165}$ And the President cannot circumvent the nominations process for judicial nominees at federal level, under Article II, Section 2, Clause 2. These factors thus protect against the destruction of environmental protection as part of a sudden 'authoritarian reversion'. I will return to the issue of judicial appointment in a different context in section 5 .

160. See generally B Rüthers, Entartetes Recht: Rechtslehren und Kronjuristen im Dritten Reich (CH Beck 1988).

161. Bundesarchiv Berlin R 22/4692, in J Noakes (ed), Nazism 1919-1945 Volume 4: The German Home Front in World War II, A Documentary Reader (University of Exeter Press 1998) 158.

162. Bundesarchiv Berlin BAB R 22/3370, in Noakes ibid 154-5.

163. See the diaries of Hans Frank, Das Diensttagebuch des Deutschen Generalgouverneurs in Polen (W Prag and W Jacobmeyer, eds, Deutsche Verlags-Anstalt 1975) 553. For an English translation see Koch (n 7) 120-21.

164. The term 'degenerated' is that of Rüthers (n 160).

165. Removal is widely thought to require impeachment under Article I; some argue that a finding of 'bad behaviour' in the ordinary courts presents alternative means under Article III, see S Prakash and SD Smith 'How to Remove a Federal Judge' (2006) 1 Yale Law Journal 74. 
There is also no equivalent of the 'Richterbriefe' in the contemporary US. Guidelines on issues such as sentencing come from bipartisan committees rather than from the office of the President or the Attorney General. ${ }^{166}$ Furthermore, the Nazi Richterbriefe only had the power they had because the separation of powers had eroded: judges might easily be dismissed under the relevant legislation if they failed to comply. The Trump administration, by contrast, would have to depend on the judiciary's willingness to adhere to informally issued guidance (perhaps via social media or public statements). Even if, therefore, we assume that Trump will radically alter the make-up of the federal judiciary so that it is filled with Trump loyalists, the very notion of judicial practice is fundamentally at odds with the anti-scientific and anti-fact stance required for a radical anti-environmentalist movement. Indeed, the judiciary in the US attaches enormous weight to consensus within the scientific community (or other experts). This respect for expertise is deeply ingrained within the very practice of judging. ${ }^{167}$ As discussed in section 5, below, this culture is hostage to change and is not protected by any hard law, but certainly, at the time of writing, on many issues, expert consensus is considered to be determinative under common law in the US. ${ }^{168}$ While far from immune to influence, the appellate court judiciary remains somewhat less partisan than other branches of government. ${ }^{169}$ That judiciary is particularly reliant on scientific evidence when it comes to environmental litigation. It is no coincidence that at the time of writing, no Trump-era act of environmental deregulation has survived a legal challenge. ${ }^{170}$ The sorts of regulatory infractions involved concern matters that are inherently to do with empirical testing, such as 'air quality', ${ }^{171}$ 'emissions standards', ${ }^{172}$ 'acid deposition', ${ }^{173}$ 'water standards' ${ }^{174}$ and 'best available technology'. ${ }^{175}$ There are thus sound reasons to believe that the anti-science Trump administration (or any similar future administration) will continue to face curtailment from the judiciary when it comes to environmental issues in any prospective dispute against individual states, even if Trump's nominees to the bench are confirmed. That said, the process of judicial nomination is one of the few areas in which the Trump administration has moved quickly and decisively. There is already a clear and well-documented danger to

166. See the United States Sentencing Commission, Guidelines Manual (Nov. 2016).

167. See E Fisher, P Pascual and W Wagner, 'Rethinking Judicial Review of Expert Agencies' (2015 ) 93 Texas Law Review 1681; as it happens, Fisher et al. use judicial review of the EPA as a case study for the use of science (and deference to expertise) in this context. Michael S Moore explores the centrality of scientific consensus about the natural world to the very concept of common law adjudication more broadly, see 'Moral Reality' (1982) Wisconsin Law Review 1061, 1143-50, 'Moral Reality Revisited' (1992) 90 Michigan Law Review 2424, and 'The Interpretive Turn in Modern Theory: A Turn for the Worse?' (1989) 41 Stanford Law Review 871, 881-91.

168. See, for example, the legal definition of 'death' in The People of the State of New York $v$ John Eulo, et al. 63 N.Y.2d 341.

169. N Devins and L Baum, The Company They Keep: How Partisan Divisions Came to The Supreme Court (Oxford University Press 2019).

170. See D Adler, US Climate Change Litigation in the Age of Trump: Year Two (Sabin Center for Climate Change Law 2019).

171. The Clean Air Act, 42 U.S.C. $\$ \S 7401$ et seq. (1970), Title I Part A, Part C.

172. Ibid, Title II.

173. Ibid, Title IV A.

174. The Clean Water Act, 33 U.S.C. $\$ 1251$ et seq. (1972), Title III.

175. Alaska Dept. of Environmental Conservation v EPA, 540 U.S. 461 (2004). 
environmental justice by way of a slower 'constitutional retrogression' in this respect. It is to this broad notion that we now turn.

\section{CONCLUSION: 'CONSTITUTIONAL RETROGRESSION' AND THE LONG-TERM THREAT}

The implication of my argument to this point is that the Trump administration will not be able to revert to authoritarianism overnight in order to override existing environmental protections, even if it secures a second term of office. The same is true of any future 'Trump-like' president. This does not, however, rule out the possibility - as just implied - that a slower erosion of constitutional norms might significantly weaken the environmental movement in the US to the extent that, eventually, such protections are eliminated (or rendered meaningless) at some point in the future. Huq and Ginsburg refer to this process as 'constitutional retrogression'; others refer to it as 'democratic backsliding'. ${ }^{176}$ It is a process whereby 'even though ... the individual steps are taken within constitutional limits, in the aggregate they yield qualitative changes in the legal and political systems'. ${ }^{177}$ Huq and Ginsburg argue that the US faces a much more credible threat from constitutional retrogression than from authoritarian reversion. ${ }^{178}$ There are numerous ways in which we can see the current administration take steps (or fail to act) in ways that such scholars have identified as likely to have this effect more broadly. ${ }^{179}$ Two are of specific concern to the environmental movement.

The first specific concern relates to judicial nomination. Trump's nominees have generally been young. They have also been, disproportionately, 'climate change sceptics'. ${ }^{180}$ There are thought to be two safeguards that would prevent an executive branch utterly transforming the federal judiciary ideologically. Neither of these is particularly effective in preventing Trump (or a Trump-like future President) from 'stacking' the Courts with climate change sceptics. The first apparent safeguard is the constitutional requirement that nominees must be confirmed by the Senate. While a President might seek to appoint members of the judiciary on the basis of conformity with his or her ideology, there is no reason to assume that the Senate will share that ideology. The confirmation process (in theory at least) is supposed to act as something of a check against an authoritarian President who seeks to transform the judiciary into a body that will simply do his or her will. For reasons discussed in section 3, above, there are few grounds for optimism that a judicial nominee will fail to be confirmed purely on the basis of an anti-environmentalist record (at least given the current makeup of the United States Senate). ${ }^{181}$

176. See N Bermeo, 'On Democratic Backsliding' (2016) 27(1) Journal of Democracy 5.

177. Huq and Ginsburg (n 122) 122. This form has become far more common than 'authoritarian reversion', ibid, 118-23. Huq and Ginsburg identify three broad elements to this type of slow erosion: a decline in the quality of elections; incursions onto rights of free speech and association; and a slow decay in the rule of law.

178. Ibid 143-69.

179. Space (and the specific focus of this essay) prohibits discussion of the first element that Huq and Ginsburg identify, a decline in the quality of elections. The Trump administration has undermined the electoral process in multiple ways, ibid 163-5.

180. See Hejny (n 1) 202-3.

181. More generally, Huq and Ginsburg note that congress is as likely to enable as to restrain an anti-democratic US president (n 122) 145-8. 
The second apparent safeguard is a convention rather than a regulation: the American Bar Association (ABA) grades all potential federal judicial nominees on the basis of their suitability for office. Presidents usually only nominate individuals if they have been given a rating of 'qualified' or better; the vast majority of nominees are rated as 'well qualified' or better. There is no strict legal requirement for a President to only nominate 'qualified' judges. But this norm is very significant in terms of the argument presented here. I noted in section 4.4 that an inherent reliance on scientific consensus is part of common law judicial culture and that this offers some protection against the anti-science agenda of the Trump administration. But any erosion of the norm that only 'qualified' judges are nominated will jeopardise this protection. An utterly unqualified judge (a layperson, for example) cannot be assumed to have the same reliance on scientific consensus. If the federal judiciary were to be replaced, over time, with 'unqualified' judges, the culture may well change. Trump has ignored the convention of only nominating ABA approved judges. Several Trump nominees have been rated 'Not Qualified' overall. Before Trump, only two nominees had ever received unanimous 'Not Qualified' ratings by the ABA. Trump has already put forward a further two nominees with such a rating. The most recent such nominee to actually be confirmed has virtually no trial experience: he has never served as either lead counsel or co-counsel in a trial. ${ }^{182}$ Thus, while Trump may not be able to suddenly transform the judiciary as the Nazis did, his unfettered power to nominate unqualified climate change sceptics loosens the protections afforded by judicial culture discussed in section 4.3. ${ }^{183}$ This is so not only because of the potential damage that such judges might inflict on environmental protection but also because of the attendant philosophy of prejudice that such an outlook requires. Any dilution of the norm within judicial culture that decisions should be led by empirical evidence poses a severe risk to environmental protection.

A further specific threat to environmental protection lies in the use of executive power to limit the amount of public information available. A flourishing democracy is dependent on access to such information. ${ }^{184}$ In the absence of adequate information, the choices that an electorate makes can more easily be manipulated by those in power. If people do not know about or understand the relevant issue, a vote on that issue is only democratic in a very limited sense. Huq and Ginsburg refer to this threat as a 'limitation of the public sphere'. ${ }^{185}$ This threat to democracy generally poses a more specific threat to environmental protection. Evidence of damage is needed to convince people to live more responsibly. In terms of public information, the Trump administration has instructed EPA employees not to release climate change data to the public. ${ }^{186}$ In a hearing related to this issue, the chair of the EPA's Board of Scientific Counsellors was pressurized to alter her testimony to the Science,

182. See PT Moxley, Chair of the ABA Standing Committee on the Federal Judiciary, Letter to the Senate Committee on the Judiciary, Re: Nomination of Justin R Walker to the United States District Court for the Western District of Kentucky, July 30th 2019, available at <https://www. americanbar.org/content/dam/aba/administrative/government_affairs_office/2019-07-30NQrating-Justin-R-Walker.pdf?logActivity=true $>$ accessed 25 October 2019.

183. See S Hawkins, 'Trump's Dangerous Judicial Legacy' (2019) 67 UCLA Law Review 20.

184. See E Anderson, 'The Epistemology of Democracy' (2006) 3 Episteme 8.

185. They also provide several recent examples (n 122) 130-36.

186. See Sherman (n 144) 100-101. 
Space, and Technology Committee. ${ }^{187}$ The Trump administration has suppressed evidence of climate change from within the EPA, ${ }^{188}$ and sought to publically undermine both academia and the media. ${ }^{189}$ None of these institutions has acquiesced in these erosions; each has constitutional and other tools with which to resist Trump's efforts to undermine their work. But there is a longer-term danger that such efforts will become norms of behaviour for the executive branch. Trump sets a dangerous precedent whereby suppression of EPA data, attacks on the media and attacks on academic freedom become a typical part of the role of the executive. Once this happens, it becomes more likely that intrusions might be made legislatively at some point in the future. ${ }^{190}$

It is possible that reforms might be introduced after the Trump presidency so as to provide more robust safeguards against these sorts of erosions on a legislative (or even constitutional) level. Such safeguards would also facilitate environmental justice. In many respects, this would simply be an exercise in placing a political norm on a legal footing: some states have already turned the convention of presidential candidates releasing their tax returns into a hard requirement to get onto the ballot, for example. ${ }^{191}$ An analogous requirement aimed at environmental accountability would create more transparency concerning the interests that a candidate might have with respect to the fossil fuel industry and other polluters. Similar reform at a federal level could place the tradition of ABA approval for judicial nominees on a constitutional footing, and the publication of EPA data on a statutory footing. ${ }^{192}$ There is even some precedent for this sort of movement. Trump claims to model his presidency on that of the seventh president, Andrew Jackson. ${ }^{193}$ The introduction of various protections for bureaucratic agencies in the US happened largely as an incremental response to Jackson's 'spoils system' policy, which saw government agencies as branches of the President's executive power. ${ }^{194}$ But such reforms, at present, seem unlikely. They would require a sitting president to sign off on various pieces of legislation that limit his or her power, but the executive branch in the US has been consistently moving in the opposite direction since the Civil War. ${ }^{195}$

187. 'Scientist Tells her Story in Latest Partisan Battle on House Science Panel', Science Magazine online edition, 28 June 2017, available at <http://www.sciencemag.org/news/2017/ 06/scientist-tells-her-story-latest-partisan-battle-house-science-panel> accessed 29 June 2017. 188. See Friedrickson et al. (n 1); and N Schoenberger, 'Access to Information in the Age of Trump' (2018) 1 Emerging Library and Information Perspectives 13.

189. B Read, 'Truth, Masculinity and the Anti-Elitist Backlash against the University in the Age of Trump' (2018) 23(5) Teaching in Higher Education 593.

190. See L Shevtsova, 'The Authoritarian Resurgence: Forward to the Past in Russia' (2015) Journal of Democracy 22; F Zakaria, 'The Rise of Illiberal Democracy' (1997) Foreign Affairs 22.

191. Senate Bill No. 27, Chapter 121, Cal. Civ. Code $\S 6880$ et seq. The bill has already been challenged on Constitutional grounds, see '4 Sue to Block California Election Law Requiring Trump's Tax Returns', Los Angeles Times, 5 August 2019.

192. There are good reasons to resist the former step, see Maya Sen, 'How Judicial Qualification Ratings May Disadvantage Minority and Female Candidates' (2014) Journal of Law and Courts 33.

193. See P Baker, 'Jackson and Trump: How Two Populist Presidents Compare', New York Times, 15 March 2017.

194. See Huq and Ginsburg (n 122) 149.

195. G Schmitt, J Bessette and A Busch, The Imperial Presidency and the Constitution (Rowman and Littlefield 2017). 
Cultural and procedural barriers to constitutional amendment discussed earlier also make such reforms unlikely, ${ }^{196}$ as does a general trend within the appellate courts to defer to political intuitions. ${ }^{197}$ In short, such reform would take a sea-change within the political and legal culture of the world's largest polluter.

A better reason for optimism is the inherent flaw within the philosophy of prejudice itself. The philosophy of prejudice must argue against fact for much of the time. However, we saw that this strategy struggles as a norm of governance - we noted it in the tension between the Nazi leadership and the judiciary of the time (even an entirely corrupted one). We have noted it now in the judicial safeguards against the Trump administration on environmental issues. The philosophy of prejudice argues against things that people directly experience. While the far-right, in various guises has been able to sustain misinformation about 'global conspiracies' over the centuries, ${ }^{198}$ it is far more difficult to do so about the tangible, physical world. Unclean air, unclean water and the destruction of habitats for local wildlife are things that people directly observe and endure. Increasing numbers of people directly experience evidence of climate change, by which they can measure the hypothesis for themselves. This is happening now. ${ }^{199}$ As educational levels improve, so too does our understanding of the causes of such phenomena. In the 2016 election, Trump performed badly among younger voters, especially those with a university education. ${ }^{200}$

In this era of 'fake news' and 'post truth politics', it is easy to be pessimistic. Yet the environmental movement seems likely to rebound from the damage done by the Trump administration and is well equipped to combat those that might seek to follow in his path. In a society in which freedoms of speech and expression are so zealously protected constitutionally, disinformation campaigns and scientific studies are afforded broadly equal protection. ${ }^{201}$ But one can only repeat lies for so long. Reality and truth do not thereby disappear. And, in the words of Thomas Hobbes, 'nature itself cannot err': ${ }^{202}$ one would rather have it on one's side. Political movements that pit themselves against available empirical evidence will always, ultimately, be fighting a losing battle. From racial segregation to anti-vaccination, empirical evidence can only be evaded for so long. The realities of governance have already caught up with and exposed the emptiness of various campaign promises made by Trump, ${ }^{203}$ and while lies and bluster work on a campaign trail, eventually, somewhere, someone will have to live with the reality. Therein, ultimately, lies hope in the age of climate crisis and denial.

196. See Albert (n 139).

197. See Huq and Ginsburg (n 122) 146-8.

198. See Mosse (n 4) 126-45.

199. See WMO Statement on the State of the Global Climate in 2018 (World Meteorological Organization, 2019) 30-37.

200. See <http://www.pewresearch.org/fact-tank/2016/11/09/behind-trumps-victory-divisionsby-race-gender-education/> accessed 29 June 2017.

201. Huq and Ginsburg (n 122) 153-7.

202. T Hobbes, Leviathan (J Gaskin, ed, Oxford University Press 1996) 24.

203. 'Trump Said He would Save Jobs at Carrier. The Layoffs Start July 20th', Washington Post, 24 May 2017. 